\title{
New suppressors of signal-sequence mutations, prlG, are linked tightly to the $\sec E$ gene of Escherichia coli
}

\author{
Joan Stader, ${ }^{1}$ Lisa J. Gansheroff, ${ }^{2}$ and Thomas J. Silhavy \\ Department of Biology, Princeton University, Princeton, New Jersey 08544 USA
}

\begin{abstract}
Analysis of more than 100 extragenic suppressors of the lamB14D signal-sequence mutation (changes Val in the hydrophobic core region at position 14 to Asp) has revealed alterations that appear to lie at prlA (secY) and $\operatorname{secA}$ (prID), two loci known to be mutable to suppressor alleles, and a new suppressor termed prlG. One allele of the new suppressor class, prIG1, has been characterized in some detail. This suppressor counteracts, to some degree, the export defect conferred by a variety of signal-sequence mutations in two different genes, lamB and malE. Genetic analysis shows that the dominant suppressor mutations are linked tightly to, and probably allelic with, the gene secE. This result, coupled with data obtained with conditional-lethal alleles of $\sec E$ (see accompanying paper by Schatz et al.), argues strongly that SecE is an important component of the cellular protein export machinery in Escherichia coli.
\end{abstract}

[Key Words: Protein secretion; $\lambda$ receptor; outer membrane; secE]

Received March 7, 1989; revised version accepted April 14, 1989.

Escherichia coli strains carrying signal-sequence mutations have been used in genetic selections with the objective of identifying genes encoding components of the cellular export machinery. The rationale of such selections is that if the signal sequence interacts with one or more components of the export machinery, then it should be possible to obtain suppressor mutations in genes encoding these components that will restore some level of function to the altered signal sequence. This approach has been applied successfully with signal-sequence mutations in two genes of the maltose regulon, lamB (Emr et al. 1981; Trun and Silhavy 1987) and malE (Bankaitis and Bassford 1985; Ryan and Bassford 1985).

The $\operatorname{lam} B$ gene specifies an outer-membrane protein that acts both as a maltoporin to facilitate transport of maltose (Luckey and Nikaido 1980) and dextrins, and as the receptor for the bacteriophage $\lambda$ (Randall-Hazelbauer and Schwartz 1973). Accordingly, LamB $^{-}$strains exhibit a Dex (inability to use dextrins as a carbon source) $\lambda^{\mathrm{r}}$ phenotype. Such strains can still use maltose because this sugar can cross the outer membrane via other porin proteins. The malE gene specifies the periplasmic maltose-binding protein that is required absolutely for both maltose and dextrin transport (Shuman 1982).

Starting with a strain that carries a signal-sequence mutation in $\operatorname{lam} B$, suppressor mutations have been identified by selecting $D^{+}{ }^{+}$. These suppressors lie in

'Present addresses: School of Basic Life Sciences, University of Missouri-Kansas City, Kansas City, Missouri 64110 USA; ${ }^{2}$ Harvard Medical School, Boston, Massachusetts 02115 USA. two genes, prlA and prlC (Emr et al. 1981). Similar selections with malE signal-sequence mutations have revealed suppressors also at $\mathrm{prlA}$ and, in addition, $\mathrm{prlD}$ (Bankaitis and Bassford 1985; Ryan and Bassford 1985). Subsequent studies have shown that $\operatorname{prlA}$ is allelic with $\sec Y$ (Shiba et al. 1984) and that at least some of the prlD alleles lie in the secA gene (Fikes and Bassford 1989). Conditional-lethal mutations at $\sec Y$ and $\sec A$ cause a pleiotropic defect in protein export (Oliver and Beckwith 1981; Ito et al. 1983) and this combination of genetic data, coupled with recent biochemical evidence (Bacallo et al. 1986; Fandl and Tai 1987; Cabelli et al. 1988), establishes that these proteins are components of the cellular export machinery. The prlC suppressors exert their effects in a manner that is different from prlA and prlD, and the function of the wild-type PrlC protein is not yet understood (Trun and Silhavy 1989).

Evidence suggests that the signal-sequence may perform multiple functions during the export process (Stader et al. 1986; Thom and Randall 1988). Accordingly, different signal-sequence mutations may cause export defects for different mechanistic reasons. If this is true, then different signal-sequence mutations may yield different types of suppressors. A test of this hypothesis requires that selection for suppressors be performed with a spectrum of signal-sequence mutations. In the past this has been problematic because most signal-sequence mutations do not cause a severe block in export and, thus, do not confer distinctive phenotypes; indeed, some are indistinguishable from the wild type phenotypically. In the case of $\operatorname{lam} B$, for example, previous selections 
were done with a deletion mutation that removes 12 amino acids from the signal sequence. It seemed possible that new suppressors might be revealed if less drastic mutations were employed.

Using highly purified dextrins, we have been able to devise more stringent conditions for selecting suppressors of $\operatorname{lam} B$ signal-sequence mutations (Trun and Silhavy 1987). Analysis of a large number of suppressors of the mutation lamB14D again has yielded mutations that appear to reside in prlA and $\sec A$ but, in addition, a new locus (termed prlG) has been uncovered. Genetic analysis suggests that these mutations are allelic to $s e c E$, a gene described in the accompanying paper (Schatz et al. 1989).

\section{Results \\ Mutagenesis and selection of Dex ${ }^{+}$revertants of STA14D}

STA14D carries a point mutation in $\operatorname{lam} B$ that changes the valine residue at position 14 of the signal sequence to an aspartic acid residue. This substitution causes a pronounced defect in the export of $\operatorname{lamB}$ (Stader et al. 1986; Stader and Silhavy 1988). Dex ${ }^{+}$revertants of STA14D were obtained either spontaneously or following UV irradiation as described in Materials and methods. In a typical experiment, $10^{8}$ cells were spread on dextrin minimal agar, and after 2 days several hundred revertants could be identified. It is not possible from these data to calculate an accurate reversion frequency because the lamB14D mutation is leaky. Accordingly, there is substantial background growth. We observed, however, that UV irradiation increased the number of revertants by 20 -fold.

Following selection, 6-8 Dex ${ }^{+}$colonies were picked from each plate and their phenotypes on dextrin MacConkey agar were compared. If isolates from the same plate had identical phenotypes they were assumed to be siblings, and only one was examined further. Isolates that exhibited a very weak Dex $^{+}$phenotype on MacConkey agar were discarded. Of $123 \mathrm{Dex}^{+}$revertants characterized, 46 occurred spontaneously and 77 were obtained following UV irradiation.

\section{Initial characterization of revertants}

Besides the desired suppressor mutation, at least three other mutational events could confer a Dex ${ }^{+}$phenotype to STA14D: (1) Mutations that alter the structural gene for another outer membrane porin and thus bypass the requirement of LamB for dextrin entry (Benson and DeCloux 1985), (2) true revertants of the lamB14D mutation, or (3) intragenic suppressor mutations that restore function to the altered LamB signal sequence. To distinguish these possibilities, the following tests were employed.

Bypass mutations are identified simply. Since they do not cause LamB export to the outer membrane, the revertant cells remain resistant to $\lambda$. Mutations of this type are quite rare. Indeed, strains containing a deletion within $1 a m B$ revert at frequencies 100 -fold lower than that observed with STA14D under the conditions we employ.

True revertants or strains that carry intragenic suppressor mutations can be recognized because the $\mathrm{Dex}^{+}$ mutation lies in $\operatorname{lam} B$. To identify these, we used a $\operatorname{Tn} 10$ insertion that is linked to $\operatorname{lam} B$ by $45 \%$ in a transduction cross. A Pl lysate grown on a strain carrying this insertion linked to lamB14D was used to transduce each of the revertants to $\mathrm{Tet}^{\mathrm{r}}$. If the Dex ${ }^{+}$mutation lies at $\operatorname{lam} B$, then we expect that $\sim 45 \%$ of the $\mathrm{Tet}^{\mathrm{r}}$ transductants would become $\mathrm{Dex}^{-}$, owing to loss of the suppressor. In this manner, we determined that $21(17 \%)$ of the 123 revertants contain mutations linked tightly to $\operatorname{lamB}$. These were not studied further. These experiments demonstrate also that the remaining 102 must contain an extragenic suppressor mutation.

\section{Mapping the suppressor mutations}

Extragenic suppressor mutations that restore function to an altered signal sequence are likely to reside in genes that specify a component of the cellular export machinery such as prlA (Emr et al. 1981), secA (Oliver and Beckwith 1981), SecB (Kumamoto and Beckwith 1983), or SecD (Gardel et al. 1987). Indeed, suppressors have been identified at prlA (Emr et al. 1981) and $\sec A$ (Fikes and Bassford 1989) already. In addition, suppressors have been found at prlC (Emr et al. 1981; Trun and Silhavy 1987). To determine whether the extragenic suppressors mapped to any of these loci, we employed strains, which contain a Tn10 linked to each in a transduction cross analogous to that described above, to identify intragenic suppressor mutations at $\operatorname{lam} B$. In this manner we found $83(81 \%)$ suppressors linked to prlA and $12(12 \%)$ linked to $s e c A$. Although these suppressors have not been characterized further, we suspect that they represent new alleles of $\operatorname{pr} l A$ and $\sec A$, respectively.

It was somewhat surprising that no additional prlC suppressors were identified, as some alleles of this gene are known to suppress lamB14D (Trun and Silhavy 1987,1989 ). However, prlC suppression of $1 a m B 14 D$ is weak, and it is possible that these suppressors were discarded in our initial screening. A negative result from $\sec B$ was not unexpected because it has been reported that SecB interacts with precursors at sites other than the signal sequence (Collier et al. 1988; Trun et al. 1988). None of the suppressors mapped to $\sec D$.

\section{Mapping the new locus, prlG}

To facilitate mapping of the seven remaining suppressor mutations, a Tn10 insertion that was linked genetically to the suppressor locus was identified as described in Materials and methods. Initially, this was done with two of the suppressors that exhibited the highest level of suppression in phenotypic tests with $\operatorname{lamB14D}$. Subsequent transductions with a particular Tn10 insertion that was $90 \%$ linked to one suppressor revealed that it was also $90 \%$ linked to the other. Indeed, it was found 
that all of the seven remaining suppressors exhibited $90 \%$ linkage to the same $\operatorname{Tn} 10$ insertion. Given these results, it seems likely that all seven are alleles of the same gene, and tentatively we have termed this gene prlG.

Because $\operatorname{Tn} 10$ insertions confer a phenotype that can be selected simply, we decided to localize prlG on the chromosome indirectly by first mapping the linked Tn10. Initial experiments involved patch matings (see Materials and methods) with three different Hfr strains, HfrG6, AL205, and AL210, carrying the particular Tn10 insertion. We found that HfrG6 (origin 66; clockwise transfer) could transfer the Tn10 efficiently, whereas AL205 (origin 61; counterclockwise transfer) and AL210 (origin 97; clockwise transfer) could not. This suggests that the Tn10 lies between 66 and $97 \mathrm{~min}$. To map the location of the $\operatorname{Tn} 10$ insertion more precisely, matings between HfrG6 and P210 (argE thr-1) were performed selecting either for $\mathrm{Arg}^{+}$or $\mathrm{Thr}^{+}$. Analysis of the exconjugants revealed linkage of the $\operatorname{Tn} 10$ to $\operatorname{argE}$. This was confirmed by P1 transduction, which shows linkage of $46 \%$.

\section{The prlGl suppressor is dominant}

Known suppressors of signal-sequence mutations are dominant in diploid analysis. This reflects the fact that these mutations are missense mutations that alter, rather than abolish, function. To test the behavior of prlG1 in diploid analysis, we use the $F^{\prime}$ factor KLF10. This episome carries chromosomal DNA from metB to malk and therefore should carry the wild-type $\operatorname{prl}^{+}$ gene. LG9.1 is a prlG1 lamB14D strain into which recA :: kan argE :: $\operatorname{Tn} 10$ were introduced by transduction. The $\mathrm{F}^{\prime}$ factor was introduced into this strain by mating with E7127 and selection for $\operatorname{ArgE}^{+}$. Exconjugants were purified and their Dex phenotype and sensitivity to phage $\lambda$ were determined. We found these phenotypes to be identical to the parent strain LG9.1, therefore we conclude that prlG1 is dominant to the wild type.

prlG1 is linked tightly to, and probably allelic with, $\sec \mathrm{E}$

During the course of this work, Riggs et al. (1988) identified a new $\sec$ gene $\sec E$, by isolating mutants in which expression of a $\sec A-1 a c Z$ gene fusion is increased. In addition to causing $\sec A$ derepression, the $\sec E$ mutation confers a cold-sensitive growth defect that appears to result from a pleiotropic defect in protein export. Of special interest was the fact that secEcs501 exhibited $50 \%$ linkage with $\arg E$ in a transduction cross, raising the possibility that this mutation and prlG1 might affect the same gene. Consistent with this hypothesis is the fact that prlG1 and secEcs501 are greater than $90 \%$ linked as measured by Pl transduction.

To map prlG1 more precisely with respect to $s e c E$, we took advantage of a specialized $\lambda$ transducing phage isolated by S. Sullivan and M. Gottesman (pers. comm.). This phage, $\lambda U 101$, contains a $2.2-\mathrm{kb}$ chromosomal in- sert with two genes, $\sec E$ and $U$, the latter identified originally as a suppressor of nusA1. [In the accompanying paper by Schatz et al. (1989) $\lambda U 101$ is described in more detail.] We wished to determine whether $\lambda U 101$ carried prlG $G^{+}$also.

Because the prlG1 suppressor mutation is dominant, complementation tests with $\lambda U 101$ cannot be used directly to determine whether the phage carries $\mathrm{prl}^{+} \mathrm{G}^{+}$. Instead, we asked whether or not the chromosomal DNA carried by the transducing phage is homologous to prlG1 by determining whether this phage can be used to exchange alleles of prlG by recombination. $\lambda \mathrm{U} 101$ is $\mathrm{cI} 857$ and int ${ }^{-}$. Accordingly, lysogens occur primarily by recombination at the region of homology resulting in a $\lambda$ prophage that is flanked by chromosomal DNA in direct repeat. When the prophage excises, chromosomal DNA either to the right or to the left will be lost depending on the position at which the recombination event occurs. If the phage carries $p r l G^{+}$, then it should be possible to exchange the chromosomal prlG1 with the wild-type allele carried by the prophage. To test this possibility, $\lambda$ U101 was lysogenized into LG9 (IamB14D prlG1) by selecting immunity at $30^{\circ} \mathrm{C}$. As expected, the lysogen JS5 formed red $\left(\right.$ Dex $\left.^{+}\right)$colonies on dextrin MacConkey agar. As a control, we also constructed a lysogen in a wild-type background, JS4, which also formed red colonies on dextrin MacConkey agar. Cultures of these strains were grown to midlogarithmic phase at $30^{\circ} \mathrm{C}$ and then were shifted to $39^{\circ} \mathrm{C}$ for $90 \mathrm{~min}$ to induce prophage excision. Dilutions of the cultures were plated on dextrin MacConkey agar and incubated overnight at $39^{\circ} \mathrm{C}$. All colonies arising from JS4 were red $\left(\mathrm{Dex}^{+}\right)$and nonimmune. In contrast, about one-third to one-half of the colonies arising from IS5 were white $\left(\mathrm{Dex}^{-}\right)_{\text {; }}$ the rest were red, but all were nonimmune. We conclude from this result that $\lambda U 101$ carries chromosomal DNA that is homologous to prlG1. Thus, prlG1 must be linked tightly to $\sec E$ and given the export-related phenotype of prlG1, we think it likely that the suppressor is an allele of $\sec E$.

Suppression of other signal-sequence mutations by prlG1

To assess the spectrum of signal-sequence mutations suppressed by prlG1, strains were constructed containing the suppressor mutation in combination with 11 $\operatorname{lam} B$ and 4 male signal-sequence mutations. The relevant phenotypes of these strains then were compared with the phenotypes of the various mutants without the suppressor. Results obtained with the $\operatorname{lam} B$ signal-sequence mutations are shown in Table 2. We find that prlG1 has an ameliorating effect in most of the $\operatorname{lam} B$ signal-sequence mutants, however, in no case is pronounced suppression observed. Data obtained with the malE signal-sequence mutants were similar. Some suppression was observed with malE14-1, $\Delta 12-18$, and 18-1; none was observed with malE10-1 (data not shown). Again, the phenotypic effects were slight.

To provide biochemical evidence for the suppression 
Table 1. Bacterial strains

\begin{tabular}{|c|c|c|c|c|c|}
\hline Strain & Description & Source & Strain & Description & Source \\
\hline \multirow{2}{*}{$\begin{array}{l}\text { E. coli: } \\
\text { AL205 }\end{array}$} & & & E. coli: & & \\
\hline & $\begin{array}{l}\text { HfrKLl6 origin } 61^{\prime} \\
\text { counterclockwise }\end{array}$ & N. Allgood & STA104 & $\begin{array}{l}\text { STA1000 } \\
\text { malF :: Tn10 }\end{array}$ & this study \\
\hline \multirow[t]{2}{*}{ AL210 } & $\begin{array}{l}\text { HfrH } \Delta(\text { lac) opp } \\
\quad \text { origin } 97^{\prime}\end{array}$ & N. Allgood & STA105 & $\begin{array}{l}\text { STAl02 } \\
\qquad \text { malF :: Tn10 }\end{array}$ & this study \\
\hline & clockwise & & STA106 & STA104 prlG1 & this study \\
\hline \multirow[t]{2}{*}{ BW6175 } & $\begin{array}{l}\text { HfrPK3 } \\
\quad \text { argE :: Tn10 thr-1 } \\
\quad \text { leuB6 thi-1 lacY1 }\end{array}$ & B. Wanner & $\begin{array}{l}\text { STA107-131 } \\
\text { (odd \#) }\end{array}$ & $\begin{array}{l}\text { STA1000 } \operatorname{lam} B \\
\text { signal sequence } \\
\text { mutations }\end{array}$ & this study \\
\hline & $\begin{array}{l}\text { azil5 tonA21 } \\
\text { supE44 }\end{array}$ & & $\begin{array}{l}\text { STA108-132 } \\
\text { (even \#) }\end{array}$ & $\begin{array}{l}\text { STA1000 prlG1 } \\
\text { lamB signal }\end{array}$ & this study \\
\hline \multirow[t]{2}{*}{ ECB475 } & $\begin{array}{l}\text { MC4100 } \\
\quad \text { proC :: } \operatorname{Tn} 10\end{array}$ & Gardel et al. (1987) & & $\begin{array}{l}\text { sequence } \\
\text { mutations }\end{array}$ & \\
\hline & tsx $:: \operatorname{Tn} 5$ & & STA133 & STA1000 malE10-1 & this study \\
\hline HfrG6his & $\begin{array}{l}\text { HfrG6 his origin } 66^{\prime} \\
\text { clockwise }\end{array}$ & laboratory stock & $\begin{array}{l}\text { STA134 } \\
\text { STA139 }\end{array}$ & $\begin{array}{l}\text { STA133 prlG1 } \\
\text { STA1000 malE14-1 }\end{array}$ & $\begin{array}{l}\text { this study } \\
\text { this study }\end{array}$ \\
\hline JS3 & $\begin{array}{l}\text { STA14D } \\
\quad \text { malF :: } \operatorname{Tn} 10\end{array}$ & this study & $\begin{array}{l}\text { STA140 } \\
\text { STA1000 }\end{array}$ & $\begin{array}{l}\text { STA139 prlG1 } \\
F^{-} \text {araD139 } \Delta\left(\arg F_{-}\right.\end{array}$ & $\begin{array}{l}\text { this study } \\
\text { Stader and Silhavy }\end{array}$ \\
\hline LG1 & $\begin{array}{l}\text { STA1000 Tn10 } \\
90 \% \text { linked to } \\
\text { prlG1 }\end{array}$ & this study & & $\begin{array}{l}\text { lac)U169 rpsL150 } \\
\text { relA1 f1bB-5301 } \\
\text { ptsF25 deoC1 }\end{array}$ & (1988) \\
\hline LG3 & STA14D Tn10 90\% & this study & & thiA1 & \\
\hline
\end{tabular}

linked to $p r l G 1$

STA14D prlG1 (original isolate)

LG10 LG9 $\operatorname{Tn} 1090 \%$ linked to $\mathrm{prlG}^{+}$

MC4100

$\mathrm{F}^{-}$araD139

$\Delta\left(\arg F^{-}\right.$lac $) U 169$

rpsL150 relA1

flbB-5301 ptsF25

deoC1 thiA1

MCR106 MC4100 lamBs106

MM152 MC4100

zhe :: Tn10 malT

$\sec B:: \operatorname{Tn} 10$

NT106

MC4100 lamBA60

zhc :: $\operatorname{Tn} 10$

NT192 STA1000 lamBA78

$\sec B:: \operatorname{Tn} 5$

NT350 MC4100 lamBA60

zha :: $\operatorname{Tn} 10$

P210 AB1133 ompF F-

thr-1 leuB6 proA2

lacY1 supE44

galK2 hisG4

rpsL31 mnt11

argE3 thi-1 xyl-5

ara14

PB1101 MC4100 malE18-1

RL361

STA14D

MC4100 malEA12-

18

STA1000 lamB14D

STA100

STA14D

$\arg E:: \operatorname{Tn} 10$

STA101

STA102

STA14D prlG ${ }^{+}$

STA14D prlG1

STA14D

malF :: $\operatorname{Tn} 10$ this study

this study

Casadaban (1976)

Emr and Silhavy

(1980)

Kumamoto and

Beckwith (1985)

N. Trun

N. Trun

Trun and Silhavy

(1987)

R. Misra

Bedouelle et al. (1980)

Bankaitis et al. (1984)

Stader and Silhavy (1988)

this study

this study

this study

this study of the export defect caused by the signal-sequence mutations, we performed pulse-chase assays to monitor the rate of signal-sequence processing. In most cases, little, if any, effect was observed, this is not terribly surprising in light of the phenotypes. Phenotypic effects provide a much more sensitive method for detecting small changes in export efficiency than does the biochemical pulse-chase assay. With two $\operatorname{lam} B$ signal-sequence mutations, $17 D$ and $17 R$, increased rates of processing were observed (Fig. 1). These two mutations are notable because they confer moderate export defects; in other words, they are quite leaky. Accordingly, it is possible that suppression is observed more easily with these mutations under the experimental conditions employed. In any event, results with these mutations demonstrate that the suppressor works by increasing export of the mutant LamB proteins.

There is a slight, but measurable, negative effect of the prlG1 mutation on the export of wild-type LamB. The effect can be seen both in Dex and phage sensitivity phenotypes (Table 2) as well as in the pulse-chase assay (Fig. 1). This negative effect is not observed with wild-type maltose-binding protein. Although the significance of this effect is not yet clear, it provides further evidence that the prlG1 mutation affects an export-related process.

\section{Discussion}

The $1 a m B 14 D$ signal-sequence mutation confers a Dex ${ }^{-}$ $\lambda^{\mathrm{r}}$ phenotype because the mutant $\operatorname{lam} B$ precursor is exported poorly (Emr and Silhavy 1980; Stader et al. 1986; Stader and Silhavy 1988). The prlG suppressors relieve this defect by restoring export of the mutant precursor, thus allowing a greater percentage of $\mathrm{LamB}$ molecules to reach the outer membrane. This increase in functional 


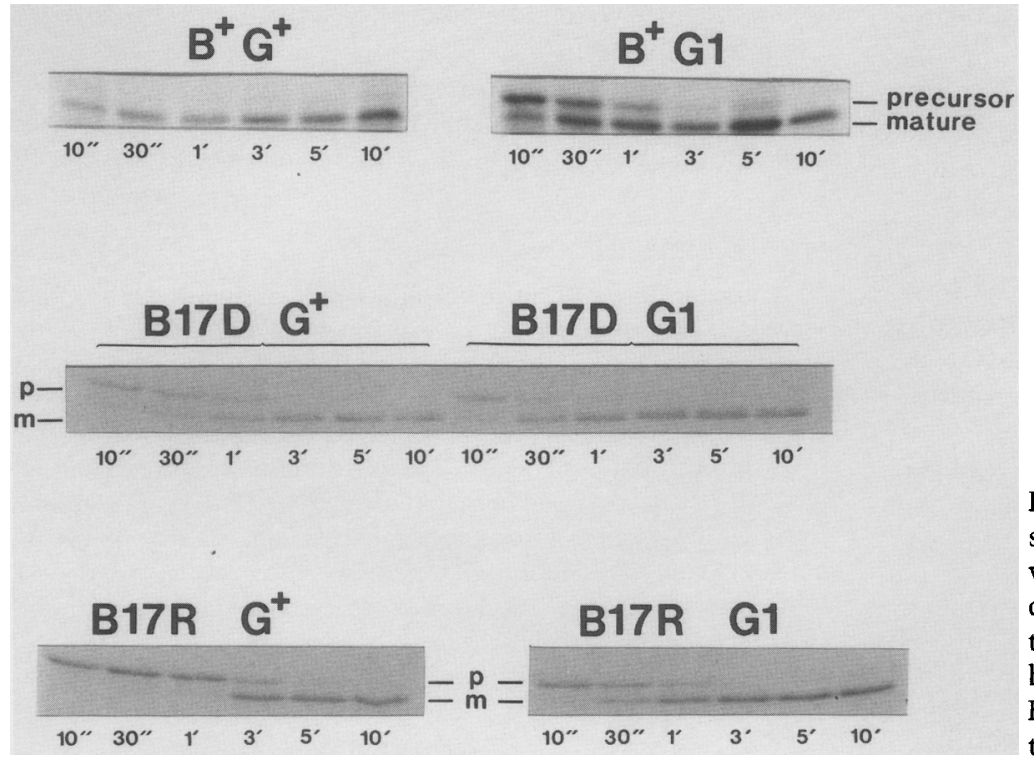

Figure 1. Kinetics of LamB processing in prlG strains. Cells were pulse-labeled as described previously (Stader et al. 1986). Chase times are as indicated. LamB was immune-precipitated and subjected to SDS-polyacrylamide gel electrophoresis, followed by autoradiography. $\mathrm{B}^{+}$is wild-type $\operatorname{lam} B ; \mathrm{B} 17 \mathrm{D}$ and $B 17 R$ are $\operatorname{lam} B$ signal-sequence mutants; $\mathrm{G}^{+}$is wildtype prlG; Gl is the prlGl suppressor allele.
LamB is evidenced by enhanced use of dextrins and a greater sensitivity to phage $\lambda$. In addition, with certain $\operatorname{lam} B$ signal-sequence mutations, an increased rate of signal-sequence processing is observed. This provides biochemical evidence for an increase in export because the enzyme responsible for this cleavage event is located at the outer surface of the inner membrane (Zwizinski and Wickner 1980).

It seems likely that suppressors of signal-sequence mutations, such as prlG, work by broadening the specificity of the cellular protein export machinery so that recognition of the mutant precursor is restored. The fact that the suppressor mutations are dominant in diploid analysis is consistent with such an altered activity and it argues against an effect caused by functional impairment. Broadened specificity could reflect a direct physical interaction between the cellular component affected by the suppressor mutation and the signal sequence, or it could occur by a more indirect means. For example, the export machinery may be a complex of different proteins and alterations in one could affect function of another. Genetic evidence to support a direct interaction would come from the demonstration of allele specificity, i.e., a certain suppressor would be specific for a particular signal-sequence mutation. However, all known suppressors exhibit rather broad specificity for signal-sequence mutations and prlG is no exception. The prlG1 suppressor affects a variety of signal-sequence mutations in both $\operatorname{lam} B$ and malE. This fact, however, should not be construed as indicating the lack of direct interaction. Given the great sequence diversity of signal sequences, inability to demonstrate allele specificity need not be surprising. The specificity of the wild-type export machinery must be quite broad as well. Thus, the potential for direct interaction between the components defined by suppressor mutations and the signal sequence remains an attractive possibility.

We have demonstrated that the prlG1 mutation lies within a $2.2-\mathrm{kb}$ segment of chromosomal DNA. This
DNA segment is known to encode two proteins, SecE and ' $\mathrm{U}$ ' (Schatz et al. 1989). Although we have no direct

Table 2. Effects of the prlG1 suppressor in various $\operatorname{lamB}$ signal-sequence mutants

\begin{tabular}{|c|c|c|c|c|c|}
\hline \multirow{2}{*}{$\begin{array}{l}\operatorname{lam} B \\
\text { allele }\end{array}$} & \multirow{2}{*}{$\begin{array}{l}\text { prlG } \\
\text { allele }\end{array}$} & \multirow{2}{*}{$\begin{array}{l}\text { Dex } \\
\text { MacConkey }\end{array}$} & \multicolumn{3}{|c|}{$\lambda$ Sensitivity } \\
\hline & & & LB & glucose & maltose \\
\hline+ & + & 1 & 1 & 1 & 1 \\
\hline+ & 1 & 2 & 1 & 1 & 2 \\
\hline $6 S$ & + & 1 & 1 & 3 & 1 \\
\hline $6 S$ & 1 & 3 & 1 & 3 & 1 \\
\hline$\Delta 60$ & + & 5 & 5 & 5 & 5 \\
\hline$\Delta 60$ & 1 & 4 & 5 & 4 & 3 \\
\hline$\Delta 78$ & + & 4 & 4 & 4 & 3 \\
\hline$\Delta 78$ & 1 & 2 & 2 & 2 & 1 \\
\hline $12 \mathrm{D}$ & + & 3 & 3 & 4 & 1 \\
\hline $12 \mathrm{D}$ & 1 & 2 & 1 & 1 & 1 \\
\hline $13 \mathrm{D}$ & + & 2 & 3 & 4 & 1 \\
\hline $13 \mathrm{D}$ & 1 & 1 & 1 & 2 & 1 \\
\hline $14 \mathrm{D}$ & + & 5 & 5 & 5 & 5 \\
\hline $14 \mathrm{D}$ & 1 & 4 & 3 & 3 & 1 \\
\hline $15 \mathrm{E}$ & + & 4 & 4 & 4 & 2 \\
\hline $15 \mathrm{E}$ & 1 & 3 & 2 & 3 & 1 \\
\hline $16 \mathrm{E}$ & + & 4 & 4 & 5 & 2 \\
\hline $16 \mathrm{E}$ & 1 & 3 & 4 & 5 & 2 \\
\hline 17D & + & 1 & 2 & 2 & 1 \\
\hline $17 \mathrm{D}$ & 1 & 2 & 1 & 1 & 1 \\
\hline $17 R$ & + & 1 & 2 & 2 & 1 \\
\hline $17 R$ & 1 & 1 & 2 & 1 & 1 \\
\hline $19 \mathrm{~K}$ & + & 4 & 3 & 3 & 1 \\
\hline $19 \mathrm{~K}$ & 1 & 2 & 2 & 1 & 1 \\
\hline $19 R$ & + & 4 & 4 & 5 & 3 \\
\hline $19 \mathrm{R}$ & 1 & 3 & 5 & 5 & 4 \\
\hline
\end{tabular}

Phenotypes were scored on a scale of 1 to 5 , with 1 corresponding to wild type and 5 corresponding to a total defect (i.e., the phenotype of a $\operatorname{lam} B$ deletion strain). Phenotypes scored as 2,3 , or 4 are intermediate, with 2 more closely resembling the wild type, and with 4 more closely resembling the deletion strain. See Materials and methods for details. 
evidence, we think it likely that the prlG suppressors are alleles of secE. Conditional-lethal mutations in $\sec E$ show defects in protein export (Riggs et al. 1988; Schatz et al. 1989|, and this relationship is compelling. Moreover, we note that prlG1 causes a slight export defect for wild-type LamB, a phenotype that clearly is analogous to that seen with known $\sec E$ alleles. In contrast, mutations in $U$ have no known effects on protein export. The fact that two completely different genetic approaches appear to have identified the same gene is striking, and it seems that this protein must play an important role in protein export.

Results presented here validate the use of suppressors of signal-sequence mutations for the identification of genes that specify components of the export machinery. More than 100 extragenic suppressors of lamB14D were characterized, and all were found to be linked tightly to genes whose products function in protein export; $81 \%$ at $\mathrm{prlA} / \mathrm{sec} Y, 12 \%$ at $\sec A / \mathrm{prlD}$, and $7 \%$ at $\mathrm{prlG} / \mathrm{sec} E$. Clearly, there is a high probability of success. Given the extent to which this approach has been applied in E. coli, it could be argued that most, if not all, of the target genes (i.e., genes that can be mutated to give a suppressor phenotype) have been identified. In other organisms, however, this approach could prove quite useful.

\section{Materials and methods}

Bacterial strains and phages

All strains are derivatives of $E$. coli $\mathrm{K} 12$ and are described in Table 1. The bacterial strains used in this study, the STA100 series, are all derived from STA14D (Stader and Silhavy 1988) and were constructed by P1 transduction.

To introduce prlG1 into the STA14D background, the strain was first transduced to $\mathrm{Tet}^{\mathrm{r}}$ with a P1 lysate grown on BW6175 (argE :: Tn10). The resulting strain STA100 subsequently was transduced to $\mathrm{Arg}^{+}$with a P1 lysate grown on LG9 (prlG1). The resulting strain, STA102 (prlG1 lamB14D) is phenotypically $\lambda^{\text {s. }}$.

The various $\operatorname{lam} B$ signal-sequence mutations were introduced into the STA14D background in a two-step procedure. First, strain STA102 was transduced to Tet $^{r}$ with a Pl lysate grown on TST6 (malF :: Tn10). This yielded two strains, STA105 (lamB14D) and STA106 $\left(\operatorname{lam} B^{+}\right)$. The P1 lysates grown on the various $\operatorname{lam} B$ mutants then were used to transduce $\mathrm{Mal}^{+}$. Acquisition of the tightly linked $\operatorname{lam} B$ allele was verified by marker rescue in all cases.

Strains carrying $\operatorname{lam} B$ signal-sequence mutations fall into two phenotypic classes; those that confer a $\lambda^{\mathrm{r}}$ phenotype (lamB alleles 12D, 13E, 14D, 15E, 16E, 19K, 19R, $\Delta 78$, and $\Delta 60$ ) and those that are $\lambda^{\text {s }}$ ( $\operatorname{lam} B$ alleles $6 \mathrm{~S}, 17 \mathrm{D}$, and 17R). To simplify identification of the desired transductant in the $\mathrm{Mal}^{+}$transduction described in the preceding paragraph, STA105 was used as the recipient for alleles that confer a $\lambda^{s}$ phenotype and STA106 was used for alleles that confer a $\lambda^{\mathrm{r}}$ phenotype. In this manner, acquisition of the desired $\operatorname{lam} B$ allele could be scored by a change in phage sensitivity in the marker-rescue experiments.

\section{Media and chemicals}

Liquid and solid media were prepared as described previously (Silhavy et al. 1984). Dextrins were obtained from Pfansteil Lab- oratories, Inc. (Waukegan, Illinois) as a malto-oligosaccharide mixture and used in the preparation of media as described by Trun and Silhavy (1987). Tetracycline was purchased from U.S. Biochemical Corp. (Cleveland, Ohio\} and used at a concentration of $25 \mu \mathrm{g} / \mathrm{ml}$.

\section{Genetic techniques}

Pl transduction, conjugation, and other standard techniques were carried out as described previously (Miller 1972; Silhavy et al. 1984). 'Patch' mating was done by growing a patch of donor $\left(\right.$ Tet $\left.^{\mathrm{r}}\right)$ cells overnight at $37^{\circ} \mathrm{C}$ on an L-agar plate and replica-plating the patches onto a plate that had been spread with a lawn of the recipient $\left(\mathrm{Str}^{\mathrm{r}}\right)$ cells. The plate was incubated at $37^{\circ} \mathrm{C}$ for $2 \mathrm{hr}$, then replica-plated onto an L-plate containing tetracycline to select for the recipients and streptomycin to counterselect the donor. The exconjugates were incubated overnight, purified by streaking, and screened for the appropriate markers.

\section{Isolation of $\mathrm{Dex}^{+}$spontaneous revertants}

The spontaneous mutants were isolated either by streaking isolated colonies of STA14D to dextrin minimal agar or by spreading $10^{8}$ cells that had been grown overnight in L-broth. The agar plates were incubated at $37^{\circ} \mathrm{C}$ for 2 days at which time revertants could be recognized as papillae that grew out of the dense background. The papillae were picked and were purified several times on dextrin minimal agar.

\section{Isolation of UV-induced Dex ${ }^{+}$revertants}

UV irradiation was employed to yield $99.9 \%$ killing as described by Miller (1972). Briefly, overnight cultures were harvested and resuspended in $0.1 \mathrm{M} \mathrm{MgSO}_{4}$. The cells were then exposed to UV irradiation of $1500 \mathrm{ergs} / \mathrm{mm}^{2}$ followed by the addition of L-broth. The irradiated cells then were grown overnight in the dark at $37^{\circ} \mathrm{C}$. Cells were then spread onto dextrin minimal agar and revertants were purified as described above.

\section{Phenotypic characterization of pseudorevertants}

LamB phenotypes of strains carrying a suppressor and a particular signal-sequence mutation were scored in several ways. To assess an increase in maltoporin function, the strains were streaked on dextrin MacConkey agar. On this media, increased LamB function correlates with an increased red color. An increase in phage receptors at the cell surface was detected by cross-streaking the mutant strains against $\lambda$ vir on various media; L-agar, maltose, or glucose minimal agar, and scoring sensitivity. On such media LamB synthesis is uninduced, induced, or repressed, respectively. Wild-type strains score as sensitive on all media; strains that express very little LamB at the cell surface are sensitive only when LamB synthesis is induced fully. malE phenotypes were scored on maltose MacConkey agar.

\section{Isolation of strains with Tn10 linked to the prlG suppressor}

A P1 lysate prepared on a population of cells containing random Tn10 insertions was used to transduce strains containing the prlG suppressors to Tetr ${ }^{r}$. Transductants that were $\mathrm{Tet}^{\mathrm{r}}$, $\mathrm{Dex}^{-}$, $\mathrm{Mal}^{+}$, and $\lambda^{\mathrm{r}}$ contain a Tn10 linked to the wild-type allele of the suppressor. P1 was grown on these strains and used to transduce the prlG mutants to obtain a $\operatorname{Tn} 10$ linked to the sup- 
pressor locus. The suppressor then was moved to a clean genetic background by transducing STA14D to Tet $^{\mathrm{r}}$ and scoring for $\mathrm{Dex}^{+}$

\section{Pulse labeling and immune precipitation}

Cell cultures were grown and pulse-labeled at $37^{\circ} \mathrm{C}$ as described previously (Stader et al. 1986).

\section{SDS-polyacrylamide gel electrophoresis and autoradiography}

Gel electrophoresis and autoradiography were carried out as described previously (Stader et al. 1986).

\section{Acknowledgments}

We thank Peter Schatz, Jon Beckwith, Susan Sullivan, and Max Gottesman for communicating results prior to publication, and Susan DiRenzo for help with the manuscript. This research was supported by grants from the National Institute of General Medical Sciences (GM-34821) to T.J.S., and by an American Cancer Society Postdoctoral Fellowship to J.S.

\section{References}

Bacallo, R., E. Crooke, K. Shiba, W. Wickner, and K. Ito. 1986. The secY protein can act post-translationally to promote bacterial protein export. J. Biol. Chem. 261: 12907-12910.

Bankaitis, V.A., B.A. Rassmussen, and P.J. Bassford, Jr. 1984. Intragenic suppressor mutations that restore export of maltose-binding protein with a truncated signal peptide. Cell 37: $243-252$.

Bankaitis, V.A. and P.J. Bassford, Jr. 1985. Proper interaction between at least two components is required for efficient export of proteins to the Escherichia coli cell envelope. $I$. Bacteriol. 161: 169-178.

Benson, S.A. and A. DeCloux. 1985. Isolation and characterization of outer membrane permeability mutants in Escherichia coli K12. I. Bacteriol. 161: 361-367.

Bedouelle, H., P.J. Bassford, Jr., A.V. Fowler, I. Zakian, J. Beckwith, and M. Hofnung. 1980. Mutations which alter the function of the signal-sequence of the maltose binding protein of Escherichia coli. Nature 285: 78-81.

Cabelli, R.J., L. Chen, P.C. Tai, and D.B. Oliver. 1988. SecA protein is required for secretory protein translocation in $E$. coli membrane vesicles. Cell 55: 683-692.

Casadaban, M.J. 1976. Transposition and fusion of the lac genes to selected promoters in Escherichia coli using bacteriophage lambda and Mu. J. Mol. Biol. 104: 541-555.

Collier, D.N., V.A. Bankaitis, J.B. Weiss, and P.J. Bassford, Jr. 1988. The antifolding activity of SecB promotes the export of the Escherichia coli maltose-binding protein. Cell $53: 273-283$

Emr, S.D. and T.J. Silhavy. 1980. Mutations affecting localization of an Escherichia coli outer membrane protein, the bacteriophage lambda receptor. J. Mol. Biol. 141: 63-90.

Emr, S.D., S. Hanley-Way, and T.J. Silhavy. 1981. Suppressor mutations that restore export of a protein with a defective signal-sequence. Cell 23: 79-88.

Fandl, J.P. and P.C. Tai. 1987. Biochemical evidence for the secY24 defect in Escherichia coli protein translocation and its suppression by soluble cytoplasmic factors. Proc. Natl. Acad. Sci. 84: 7448-7452.
Fikes, J.D. and P.J. Bassford, Jr. 1989. Novel $\sec A$ alleles improve export of maltose-binding protein synthesized with a defective signal peptide. J. Bacteriol. 171: 402-409.

Gardel, C., S. Benson, J. Hunt, S. Michaelis, and J. Beckwith. 1987. secD, a new gene involved in protein export in Escherichia coli. J. Bacteriol. 169: 1286-1290.

Ito, K., M. Wittekind, M. Nomura, K. Shiba, T. Yura, A. Miura, and H. Nashimoto. 1983. A temperature-sensitive mutant of E. coli exhibiting slow processing of exported proteins. Cell 32: 789-797.

Kumamoto, C.A. and J. Beckwith. 1983. Mutations in a new gene, $\sec B$, cause defective protein localization in Escherichia coli. J. Bacteriol. 154: 253-260.

-1985. Evidence for specificity at an early step in protein export in Escherichia coli. J. Bacteriol. 163: 267-274.

Luckey, M. and H. Nikaido. 1980. Diffusion of solutes through channels produced by phage lambda receptor protein of Escherichia coli: inhibition by higher oligosaccharides of maltose series. Biochem. Biophys. Res. Commun. 93: 166171.

Miller, J.H. 1972. Experiments in molecular genetics. Cold Spring Harbor Laboratory, Cold Spring Harbor, New York.

Oliver, D.B. and J. Beckwith. 1981. E. coli mutants pleiotropically defective in the export of secreted proteins. Cell 25: $756-772$.

Randall-Hazelbauer, L.L. and M. Schwartz. 1973. Isolation of the phage lambda receptor from Escherichia coli K12. I. Bacteriol. 116: 1436-1446.

Riggs, P.D., A.I. Derman, and J. Beckwith. 1988. A mutation affecting the regulation of a $\sec A--1 a c Z$ fusion defines a new sec gene. Genetics 118: 571-579.

Ryan, J.P. and P.J. Bassford, Jr. 1985. Post-translational export of maltose-binding protein in Escherichia coli strains harboring malE signal-sequence mutations and either $\mathrm{prl}^{+}$or prl suppressor alleles. J. Biol. Chem. 260: 14832-14837.

Schatz, P.J., P.D. Riggs, A. Jacq, M.J. Fath, and J. Beckwith. 1989. The $\sec E$ gene encodes an integral membrane protein required for protein export in E. coli. Genes Dev. 3: 10351044.

Shiba, K., K. Ito, T. Yura, and D.P. Cerretti. 1984. A defined mutation in the protein export gene within the $s p c$ ribosomal protein operon of Escherichia coli: Isolation and characterization of a new temperature-sensitive $\sec Y$ mutant. EMBO J. 3: 631-635.

Shuman, H.A. 1982. Active transport of maltose in Escherichia coli $\mathrm{K}-12$; role of the periplasmic maltose binding protein and evidence for a substrate recognition site in the cytoplasmic membrane. J. Biol. Chem. 257: 5455-5461.

Silhavy, T.J., M.L. Berman, and L.W. Enquist. 1984. Experiments with gene fusions. Cold Spring Harbor Laboratory Press, Cold Spring Harbor, New York.

Stader, J., S.A. Benson, and T.J. Silhavy. 1986. Kinetic analysis of $\operatorname{lam} B$ mutants suggests the signal sequence plays multiple roles in protein export. J. Biol. Chem. 261: 1507515080.

Stader, J. and T.J. Silhavy. 1988. A progenitor of the outer membrane $\operatorname{lam} B$ trimer. I. Bacteriol. 170: 1973-1974.

Thom, J.R. and L.L. Randall. 1988. Role of the leader peptide of maltose-binding protein in two steps of the export process. $J$. Bacteriol. 170: 5654-5661.

Trun, N.J. and T.J. Silhavy. 1987. Characterization and in vivo cloning of $p r l C$, a suppressor of signal sequence mutations in Escherichia coli K12. Genetics 116: 513-521.

Trun, N.J., J. Stader, A. Lupas, C. Kumamoto, and T.J. Silhavy. 1988. Two cellular components, PrlA and SecB, that recog- 
Stader et al.

nize different sequence determinants are required for efficient protein export. J. Bacteriol. 170: 5928-5930.

Trun, N.J. and T.J. Silhavy. 1989. PrlC, a suppressor of signal sequence mutations in Escherichia coli, can direct the insertion of the signal sequence into the membrane. $J$. Mol. Biol. 205: 665-676.

Zwizinski, C. and W. Wickner. 1980. Purification and characterization of leader (signal) peptidase from Escherichia coli. J. Biol. Chem. 255: 7973-7977. 


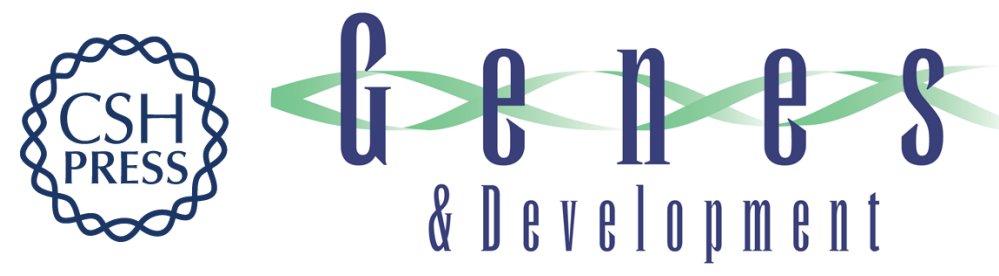

\section{New suppressors of signal-sequence mutations, prIG, are linked tightly to the secE gene of Escherichia coli.}

J Stader, L J Gansheroff and T J Silhavy

Genes Dev. 1989, 3:

Access the most recent version at doi:10.1101/gad.3.7.1045

References This article cites 31 articles, 19 of which can be accessed free at: http://genesdev.cshlp.org/content/3/7/1045.full.html\#ref-list-1

License

Email Alerting

Service

Receive free email alerts when new articles cite this article - sign up in the box at the top right corner of the article or click here.

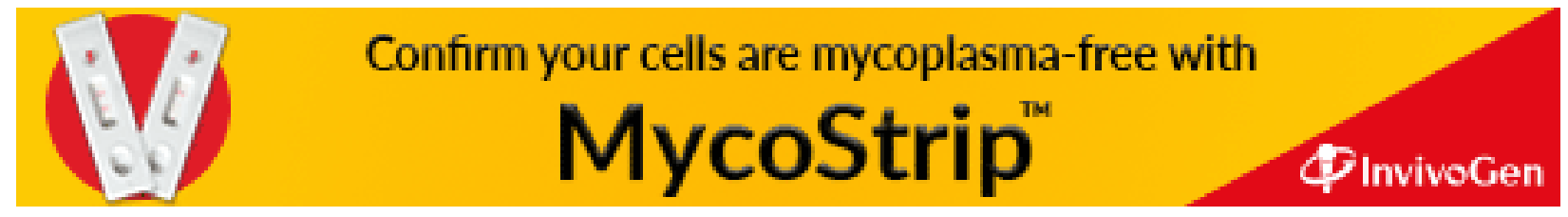

